\title{
Impact of Globalization on the Traditional African Cultures
}

\author{
Kabiru Ibrahim Yankuzo \\ School of Remedial and Basic Studies \\ Federal Polytechnic Kaura Namoda, Zamfara State, Nigeria
}

\section{Doi:10.5901/jesr.2013.v3n9p43}

\begin{abstract}
There has been increasing concern over the years by the scholars and writers on how the world is being compressed into a single space now referred to as 'a global village'. Countries at various stages of development are increasingly forced to take account of an ever expanding interconnection of socio-cultural issues and economies in the management of their national affairs. The states are increasingly losing their capacity to govern and to regulate in an increasingly borderless world; with an increasing homogenization and domination of traditional African cultures. African societies are forced into accepting uniform moral principle of what is right and wrong within the global cultures. Scholars and writers often focus attention on economic aspect of globalization, while neglecting other aspects, more importantly its cultural aspect. This paper seeks to examine what exactly is globalization, and how can we best conceptualize this phenomenon? Lastly what are its impacts on the development of African cultural norms and values? These amongst others are the questions, which this paper seeks to examine using cultural convergence perspective as a guide.
\end{abstract}

\section{Introduction}

Globalization is a critical tool for cultural homogeneity and end to cultural diversity in the world. The cultural and linguistics differences accompanying ethnic divisions in Africa have been weaken by the forces of globalization. Africans traditional cultural values are being replaced by the global cultural values. Scott and Marshall (2005) argue that global culture is brought about by varieties of social and cultural developments which include the existence of world satellite information system, the emergence of global patterns of consumption and consumerism, the cultivation of cosmopolitan life-styles, the emergence of global sport such as the Olympic games, the spread of world tourism, the decline of the sovereignty of the nation state, the growth of global military system, recognition of a world-wide ecological crisis, the development of world-wide health problems such as Aids, the emergence of world political systems such as the League of Nations among others.

Perhaps one can say nearly every nation and the lives of billions of people throughout the world are being transformed, often quite drammatically, by globalization. The degree and significance of its impact can be seen almost everywhere.

\section{Concept and Perspectives of Globalization}

Different authors and scholars depending on their perspectives have viewed globalization in various ways. Giddens, (1997) defined globalization as the intensification of world-wide social relations, which link distant localities in such a way that local happenings are shaped by events occurring many miles away and vice-versa. Abdurrahman and Kura (2013) conceptualized globalization as a complex phenomenon that underlines a multiplicity of linkages and interconnectedness surpassing the nation-state. It is a process that brings various agents, issues, events, actions, into a complex web of relationships and interactions. Here, emphasis is simply on the integration of politics, 
economics and homogenization of global cultures. Similarly, Ritzer (2008) defined globalization as the spread of worldwide practices, relations, consciousness and organization of social life. Globalization has also been defined "as a coalescence of varied transnational processes and domestics' structures, allowing the economy, politics, culture and ideology of one country to penetrate another. The chain of causality runs from the spatial reorganization of production to international trade and to the integration of financial markets" (Mittleman, 1997:3)

Globalization therefore, has a multi dimensional process whereby cultural, economic and political relations increasingly take a global basis. It involves many agents or actors that are instrumental or are direct players in the process; these actors or agents according to (Ritzer, 2008; Liman and Onyetube, 2013) include Transnational Corporations, the multilateral institutions like the World Bank, I MF, WHO, WTO, etc. and the media.

It is this multifaceted nature of globalization that makes it perhaps the most important and pervasive phenomenon facing humanity-western and non-western. Globalization is like an uncontrollable wildfire it has started and nobody knows where it is taking us. What is evident is that no person, family, religion and society are immune to it. It is therefore shaping our society's labor markets and its pattern of inequality, its consumption and its health as well as its political stability and legitimacy. Globalization is a reality for all of us because; we are forced with no any option but to live in a global village.

Perspectives: there are different perspectives in understanding and analyzing globalization depending on the focus of the paper/study. However, globalization can be analyzed culturally, economically, politically and institutionally. Culture is the dominant perspective in this study. Jan Nederveen Pieterse (cited in Ritzer, 2008) has identified three major paradigms in theorizing the cultural aspects of globalization in 2004, specifically on the centrally important issue of whether cultures around the globe are eternally different (cultural differentialism), converging (cultural convergence) or creating new hybrid forms out of the unique combination of global and local cultures (cultural hybridization).

According to Ritzer (2008) those who adopt cultural differentialism argue that among and between cultures there are lasting differences that are largely unaffected by globalization in this perspective, globalization occurs only on the surface, and the deep structure of cultures is largely, if not totally, unaffected by it. In contrast, the cultural convergence paradigm is based on the idea of globalization leading to increasing sameness throughout the world. This is to say cultures changing, sometimes radically, as a result of globalization. While the cultural hybridization emphasizes the mixing of cultures as a result of globalization and the production, out of the integration of the global and the local of new and unique hybrid cultures that are not reducible to either the local or the global cultures.

Cultural convergence is the most relevant perspective in this study, therefore, it is adopted to serve as a guide in understanding the impact of globalization on African cultures. The reason is that the cultures of the world are seen as growing increasingly similar, at least some degree and in some ways. There is a tendency to see global assimilation in the direction of dominant groups and societies in the world especially western and Americans. This is simply cultural imperialism, westernization and Americanization of the weaker societies.

\section{Impact of Globalization on African Cultures}

What we describe today as Africa does not exist as one entity during the pre-colonial days. The various communities which make up Africa today were developing in their own ways before the colonial factors intervene. Indeed, what existed then were various types of state organizations at various stages of development. These included empires, kingdoms, clans/villages, organizations among others. Such communities have already had their developmental process socially, economically, politically and medically but retarded by the European imperialism, which has manifested itself now in the form of globalization. What follows below is a discourse on the central 
theme of the paper, i.e. how globalization impacted on the traditional African cultures, considering its adverse effects on: traditional African family; indigenous/traditional medicine; education as well as its economic and political dimension in Africa.

\section{Traditional African Family}

Family is the backbone and basic unit of every society. Some form of family exists in all human societies. The forms, process, and rules which govern family, however, differ from one society to another. Alubo, (2012) defines family as a group of people who are united by blood relationship and/or marriage which functions as a social and economic unit.

In the traditional African society, just before the rapid widespread of western imperialism and contemporary globalization, there was one type of family: the extended family system, which included a man, his wife or wives and their children, relatives and in some sense, children of the man's friends (UKA. 1969). There was good understanding, unity and feeling of oneness among the traditional African families. UKA (1969) maintained that the relationship among siblings in African culture was generally very cordial and that extended family system made it possible for members to help one another and contribute to the support of the extended family. This shows that the relationships between a child and another child was not one of dominance of one member by the other, but one of love, protection, care and respect. Obidi (2005) is in support of the assertion that extended family encouraged the development of we-feeling and members were conceived as a team, working together for the welfare and prosperity of the family. Interdependence was stressed and the welfare of all superseded the welfare and interest of the individual. In fact, traditional African families were well built, well fed, well dressed and well-to-do based on their customs and traditions.

Influx of western imperialism into Africa changed the African social structure and the pattern of family life. The western societies were ethnocentric in their belief that African cultural traditions are inferior and primitive and should be de-emphasized. And that still many Africans have it somewhere at the back of their minds that; the more their buildings, music, dressing and even food appear western. The more civilized they think they are. To be civilized then will mean to be able to think, eat, walk and speak like Europeans and Americans which is simply cultural imperialism and globalization.

We as human are shaping and affecting globalization and globalization is shaping and affecting us. One of the consequences of globalization is the end of cultural diversity and the triumph of a homogenized culture serving the needs of transnational corporation. Hence, the world eats tinned food, drinks Coca-Cola, works in industry, watches European champion leagues, World Cup, African Cup of Nations, American movies, whilst the African traditional values decline in importance. Such global commodities imply the emergence of global culture, modernity and westernization. The impact of globalization is demonstrated in situation where the socio-cultural organization of African societies such as kinship, community organizations etc. that used to bind members together were weakened by the forces of globalization. The Nike Sport Fashion and other sport wears and unsuitable tight dress have become the standard dress of the youths; the rich have become most prestigious members of today's society. Extended family system is characterized by misunderstanding, disunity, hostility, dominance of one member by the other and self-interest rather than family interest. The subsistence agricultural production was left for capitalist mode of production. The implication is not only in terms of its negative impact on our customs and traditions but also detrimental to economic development process of African societies.

Indigenous Education: - education is essential for the transmission of society's norms and values. Haralambos (1980) maintained that in small scale, non-literate societies, such as hunting and gathering bands, formal education was unknown. Young people learned their lessons for life largely by joining in the daily round of the social group. Similarly Obidi (2005) observed that children's education began in the nuclear and extended family circles. During family meetings and 
visits to relatives, children learned about their origins, ancestors, gods, heritage and the origin of annual festivals. One may add that every member was taught to acquire positive personality traits like honesty, hard work, courage, endurance and sociability.

According to Obidi (2005) the majority of people in traditional society were given education at childhood level which enabled them to participate in various occupations, ranging from agriculture and allied activities to manufacturing, craftsmanship and trading. This indicates that most of the people in the traditional African societies farmed, some hunted for fames, some fished and others used local and imported resources to produce goods distribute and sell commodities. In this way we have seen that indigenous education played a vital role in the transmission of culture from one generation to the next, and in the ordering and regulating of social life as well as in leading people to know how to contribute to the economics development of their societies just before the introduction of formal/institutional education.

The introduction of western/institutional education in Africa was part of the globalizing process of western expansion. Today we receive education in the class room, using laboratories equipped with chemicals and internet facilities produced by the transnational cooperation. The implication here is our resources that would have been used for other developmental activities have now been diverted to the purchase of the internet and laboratory facilities. Furthermore, much of our knowledge of the world is gained directly through the media especially, about people, places events and how to make sense of the world. Mass media as an agent of socialization has become an integral part of our everyday life, reaching our children, organizing their entertainment and social life. A source of information and ideas regarded as authoritative and trustworthy, Hollywood, CNN, BBC e.t.c. are examples of such media houses whose main interest is westernization and Americanization of other societies.

\section{Traditional Diagnostic and Therapeutic System of Care in Africa}

A number of scholars (Mbiti, 1969; Gusau, 1981; Oke, 1982; Tahzib 1983) have shown that Africa had its own system of health care before the advent of colonialism and the introduction of western medicine. Mbiti (1969) observed that "every village in Africa has a medicine-man within reach, and he is the friend of the community. He is accessible to everybody and at almost all times, and comes into the picture at many points in individuals and community life." In other words the various cultures had developed their medical system in line with their needs. There were various categories of practitioners of the art within these cultures. These traditional practitioners maintained the health needs of the population and included specialists like bone-setters, herbalists, midwives, diviners, magician-healers, oracle men (Mbiti, 1969; Oke, 1982; Tahzib, 1983.) these practitioners were traditionally compatible with their client (patient). For instance, Gusau (1981) noted that Hausa/Fulani people of Nigeria share the belief that traditional bone setting is generally believed to be better than the one done in hospitals. While Mbiti (1969) observed that Azande is an ethnic group in the East Africa, what ever the nature of disease, illness, misfortunes, the Azande attribute the cause to witchcraft while requires a witch doctor for its care. These observations support the fact that the traditional practitioners were highly ubiquitous and the services rendered were in consonance with the socio-economic conditions of the African as it is with other parts of the developing world.

In spite of these, the liberalization and globalization policies of the United Nations Institution continue to hinge on free market forces which have continued to negatively affect the structures of the developing economies-Navarro (1976) argued that health and medical care are inextricably linked with the capitalist system of production brought about a commodity production of health care giving rise to various form of inequalities in the distribution and access to health care and medical resources. In addition to the social inequality, one can add that hospitals are globally organized into medical departments, each requires global equipments produced by the Multinational Corporations (MMCs), so as to improve the economic development of Europe and 
America. Navarro (1976) observed that illness is open to exploitation by the practitioners of medicine and the transnational corporation in the manufacture and distribution of drugs and hospital equipment. State's intervention has involved the establishment of policies and programs which do not conflict the interest of health service producers and medical industrial complex involved in the production and selling of drugs and hospital supplies.

The implication of the efforts made by the colonial administrators to suppress traditional medicine is enormous for the fact, that there are countless number of people now in Africa striving for better health at every level of the global health care system but it remains difficult. The widen gap between the rich and the poor has denied the poor one access to better health and this adversely affect our development process. Navarro (1976) asserted that the exploitation of Africa, Asian and Latin American countries by the core capitalist nations of Europe through colonial and non-colonial linkages like globalization is identified as the root cause of underdevelopment of health and medical care resources of those nations.

\section{Economic and Political Dimension of Globalization in Africa}

The traditional African societies were well known as skilled craftsmen engaged in the production and trading of different types of goods prior to the advent of colonialism. Among these were agricultural activities like chair making, pottery, leather goods, wood carvings, baskets e.t.c. These created job or employment opportunities for people. For these reason, according to Onyetabe and Liman (2013) there are indications that the pre capitalist, social formations have experienced a high level of productivity that might have been distorted by imperialism which manifests itself in the form of westernization, liberalization and now globalization.

Economic globalization has to do with increased economic interdependence and integration of all national economies into one global economy. Abdurrahman and Kura (2013) noted that globalization has two important dimensions: the first is concerned with economic aspects, which comprises trade, investment, technology, cross border production systems, information flows and communication; and the second deals with increased homogenization of policies and institutions in the international system on trade and capital market liberalization, standardization of policies and so on. Here, emphasis is simply on economic interests that profess breaking down of national economic barriers; the international spread of trade, financial and production activities, and the growing power of transnational corporations and international financial institutions.

Since it is the US, Western Europe and Japan that continue to account for the bulk of capital that propels globalization, then it can be argued that countries of the periphery, Nigeria and other African countries can reverse the underdevelopment tendencies under the new international division of labor and power (Ugwukah and Michael, 2010). The emergence of World Trade Organization (WTO) in 1995, world leading industrialized countries began to expand the scope of trade and investment agreements primarily to strengthen their position and dominance in a hitherto global world of inequalities. Ogunlana (2004) stated that the justification for expanding WTOs scope by the developed countries was chiefly to secure foreign investment and ensure free and unrestricted access to market through application of the general agreement on tariffs and trade.

From the foregoing, globalization with unrelated and unequal component cannot be said to be global effort to unite or foster even development. Rather, it is a calculated attempt to subdue and dominate others by western society. This has fundamental implications for the developing countries in general and Africa in particular that on one hand are being asked to open up, while on the other find the world market place impossible to penetrate this brings us to the world without borders.

Another dimension to the globalization debate is the political. Those that adopt political approach tend to emphasize the near importance of the state in the era of globalization. According to Ugwukah and Michael, (2010) the tread of globalization in its dynamics, in the integration of capital, goods and services is likely to undermine not only the sovereignty of states, but also make 
it less important in the conduct of foreign relations.

One of the most important issues in the globalization process is the question of boundary and identity as they relate to economic, social and political process. For instance, the borderless of globalization can create serious problem for national government that may find it difficult to control the Transnational companies (TNCS) on behalf of their national interests.

Furthermore, the universalization of western form of democracy has increasingly become the final form of government across the globe. This can also be demonstrated in series of protests demanding for democratic government in the Arabian nations. In addition and related to the above, is that the rise in importance of such transnational bodies as World Bank, IMF, UN and AU introduces new agents into decision making process of which the nation-states have to negotiate and contend with. Thus, the incursions of international organizations upon national sovereignty is restricting the ability of the state to uphold its own fundamental values which of course is the situation in Africa.

\section{Conclusion}

In conclusion, it is argued in this paper that globalization of culture in Africa is nothing but cultural imperialism manifesting through the domination of the indigenous culture both in the materials and non materials modes by the foreign cultures. The paper also shows how cultural imperialism adversely affected the indigenous family structure, traditional diagnostic and therapeutic system of care in Africa and how African pre-colonial economies were destroyed or incapacitated by the forces of globalization. Though western civilization has many good things to appreciate, overemphasis on it at the detriment of our cultures is not good for our development derive, to neglect our cultural heritage is to abandon a good chunk of the criteria that determine our wholeness and originally. Therefore, there is need for proper education on the African cultural heritage in the continent. To be educated is to be intellectually, morally, physically, psychologically, socially, spiritually as well as culturally balanced.

\section{References}

Abdurrahman A.D. and Kura Y.S. (2013) Globalization: an Introduction. In Abdurrahman A.D. and Kura Y.S. (eds) Work and Productivity in the Era of Globalization. The Nigerian Experience, I badan: Focus Publishers.

Alubo 0. (2012) Sociology: A Concise Introduction \os: I chejum Press.

Giddens, A. (1997). The Consequences of Modernity. Cambridge Polity Press.

Gusau G.A. (1981) Traditional Medicine, its Practitioners and their Patient, in Sokoto-Nigeria. An unpublished B.sc Project, Sociology Department Usmanu Danfodio University Sokoto.

Haralambos M. (1980) Sociology: Themes and Perspectives: London: Oxford. University Press.

Liman A. and Onyetube J.E. (2013). Globalization and Trans-border Trade: Implication for Work and Productivity in Nigeria. In Abdurrahman A.D. and Kura Y.S. (eds) Work and Productivity in the Era of Globalization: The Nigerian Experience, I badan: Focus Publishers.

Mbiti S.J. (1969) African Religions and Philosophy, London: Edinburgh.

Mittleman, James H. (1997) "How Does Globalization Really Work" Mittleman, James H. (ed) Globalization: Critical Perspectives, Boulder: Lynne Rienner.

Navarro, V. (1976) "Social Class, Political Power and the State and their Implication for Medicine". International Journal of Health Services 4:527

Obidi S.S. (2005) Culture and Education in Nigeria: A Historical Analysis; Ibadan: University Press PLC.

Ogunlana, O.A (2004) "New Issues for Negotiation under the World Trade Organization (WTO) and the Implication for Developing Countries" Bulletin Publication of the Central Bank of Nigeria. Volume 28:4.

Oke E.A. (1982) Traditional Health Services. an Investigation of the Providers and the Level and Patterns of Utilization among the Yorubas, I badan, University of I badan Department of Sociology. 
Ritzer G. (2008). Sociological Theory. New York, Megrow Hill Publishers.

Scott, J. \& Marshal, G. ed. (2005). Oxford Dictionary of Sociology: University Press

Tahzib, F. (1983) Traditional Medical Practitioners and Specialist in Northern Nigeria. The International Seminar on Hausa Studies, University of Sokoto.

Ugwukah C.A. \& Michael E.A. (2010) An Introduction to International Relations, Ibadan: Abba Press Ltd. Uka, N. (1969) Growing Up in Nigerian Culture. I badan: Ibadan University Press. 
